\title{
Computer Programs
}

Abstracts of computer programs of interest to subscribers may be submitted to the Journal. Descriptions should not exceed 100 words. The equipment used and the name and affiliation of submitter should be added.

\section{Instructions to Authors}

Manuscripts in the areas of finance and quantitative analysis should be sent to the editor. Two copies should be enclosed and the authors' names should not appear on the manuscript to preserve anonymity. The manuscripts will then be forwarded to the appropriate associate editors. Manuscripts should be typed on $8 \frac{1}{2} \times 11$ paper and should be double-spaced. Ma.thematical notation should be kept as simple as possible. Where at all possible use common typewriter characters such as primes, slashes, asterisks, etc. Use power $\frac{1}{2}$ rather than square foot.

Footnotes should be numbered consecutively and typed in a separate list a.t the end of the paper. Do not use footnotes on mathemat1cal symbols. Reference material should be listed alphabetically on a separate sheet at the end of the manuscript.

The following subject matter areas are representative of the interest of the Journal. The list is not all inclusive nor are the areas listed mutually exclusive.

$\begin{array}{ll}\text { Business Finance } & \text { Statistics } \\ \text { Investments } & \text { Operations Research } \\ \text { Banking } & \begin{array}{l}\text { Management Sclence } \\ \text { Financial Institutions }\end{array} \\ \text { Monetary Theory and Policy } & \text { Information Theory and Technology } \\ \text { Credit } & \text { Risk and Uncertainty Analysis } \\ \text { Consumer Finance } & \text { Decision Theory } \\ \text { Real Estate Finance } & \text { Insurance } \\ \text { International Finance } & \text { Financial Aspects of Non-Profit } \\ & \text { Organizations }\end{array}$

